\title{
The Traditional Games As A Means of Learning Resources Two Dimensional Figures In Primary School
}

\author{
Desi Setiyadi $^{1}$, Zaenuri², Mulyono², Nur Karomah Dwidayati \\ ${ }^{1}$ Primary of Education, Graduate School, Universitas Negeri Semarang, Indonesia \\ ${ }^{2}$ Department of Mathematics Education, FMIPA, Universitas Negeri Semarang, Indonesia \\ Corresponding email: desisetiyadi12@gmail.com
}

\begin{abstract}
The purpose of this research was to explore the traditional games as a means of learning resource two dimensional figures materials in primary school. The research was conducted in the area of Banyumas by observing a wide variety of traditional games that have relevance to mathematical concepts. The research method applied was survey method. The data collection technique was done through observation, literature review, and documentation. The results showed that Banyumas various traditional games such as engklek (hopscotch), damdaman (checker), gobak sodor and bandaran is related to etnomatematics learning, which is the concept of two dimensional figure.
\end{abstract}

Keywords : Culture, Traditional Games, Two Dimensional Figures

\section{Introduction}

Globalization has affected a shift in the value of life embraced by the citizens of the nation (Fauzi, 2016). The need for awareness of Indonesian life to be able to filter the culture of Western culture must be done, so that a genuine culture of Eastern nations, especially Indonesia is not lost and can co-exist with the times. Traditional games in various remote areas of Indonesia has considered to be endangered culture in Indonesia. One of the example is the traditional games in the area Banyumas Regency, Central Java, Indonesia.

Kusnandar \& Nurcahyo (2017) states that traditional games as the nation cultural assets to be preserved, explored and cultivated over the times. In addition, traditional games can be used as a learning resource for students, especially math. The design of the arena, tools and materials in traditional games can be used as a means of learning for students to introduce themselves with the concept dimensional figures of math in primary school.

Hiebert and Carpenter (1992) revealed that the teaching of mathematics in schools and student mathematics are found in everyday life will be very different. Therefore, the traditional game is a bridge between mathematics with students daily lives, so that learning was impressed play while learning. Hudojo (1998) stated that learning while playing is a learning theory of Dienes in which there are six stages, one of which is a game that uses the rules.

Basic education, particularly in primary school consist of geometric figures material. The examples of geometric figures are square, rectangular, triangular, trapezoid, parallelogram, rhombus, kite and circles. It is stated in the syllabus of mathematics of Curriculum 2013 in primary school in the subject matter of geometry and measurement.

The mathematical concept dimensional figures can be obtained by students in the traditional games, since mathematics is derived from the culture. This is in accordance with Raymond (Gie, 1999) who states that it can not be denied that mathematics is one of the most important part of the culture in every modern society. Mathematics originating from the culture often called etnomatematics. It is a mathematical grow and develop in a particular culture (Joseph, 2010).

Based on observations conducted in Banyumas, there were a wide variety of traditional games such as engklek (hopscotch), dam-daman (checker), gobak Sodor, and bandaran. The results of the research conducted by Setiyadi, Zaenuri \& Mulyono (2018) states that the learning process of etnomatematics with traditional games can make students more interested in the course.

\section{Method}

This research applied research methods survey. The research was conducted in the area of Banyumas Regency, Central Java, Indonesia. The location and the subject of the study was conducted by using purposive sampling. The steps of survey method conducted in this study were as follows, 1) study of literature, 2) data collection in the field, 3) description, and 4) an 
analysis of findings from the field (factual model).

To conclude, the activities carried out consisted of several activities, as follows, 1) explored the traditional games culture in the area Banyumas, 2) analyzing the relationship of traditional games with the concept two dimensional figures as a means of mathematics learning resources in primary school. The data collection technique was done by using observation, literature review, and documentation. The analysis of the data used in this study was descriptive qualitative.

\section{Results and Discussion}

The research which was carried out have been successful in exploring the traditional games culture in the area of Banyumas Regency, Central Java, Indonesia such as engklek (hopscotch), dam-daman (checker), gobak Sodor, and bandaran.

\subsection{Engklek Game (Hopscotch)}

Engklek is a traditional games of jump by throwing gacuk on a flat plane that is drawn on the ground with several shapes, they are a square, rectangle, triangle and circle and played by minimum 2 players. The arena and gacuk of engklek can be seen in Figure 1.
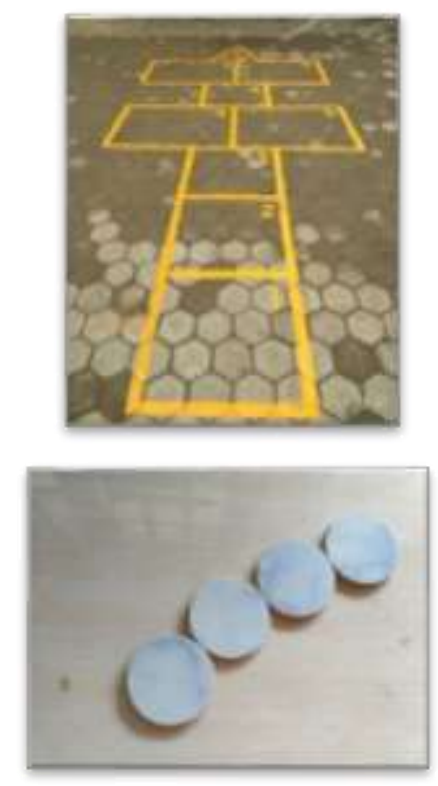

Figure 1. The Arena and Gacuk of Engklek

The rules of engklek are as follows: 1) the players determine who plays at first by whistling or hong ping pah, the winning player will play at first, and the losers shall wait to take turn to play, 2) the player throwing the gacuk to the area closest to the player, as shown in Figure 1 gacuk thrown at number 1,3 ) players jumping on one leg (dengklek) in the area of the square and the triangle, and use two feet in the areas of rectangular in shape, as shown in Figure 2, 4) the player must pass through all the regions in the arena, 5) the player throwing gacuk a way to reverse the body, if gacuk fell on one of the arena, then the players get the area as the player paddy 6) players can stand as it passes through the fields using two legs in the game, 7) usually the fields marked by the player with star image.
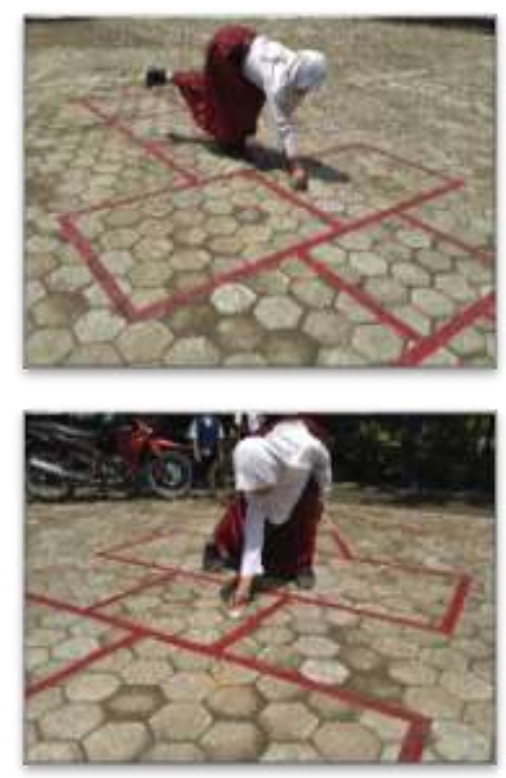

Figure 2. The Position Players in The Region of Square and Rectangle

As can be seen in Figure 1, it can be identified that the playground of engklek are in the form of square, rectangular, and triangular. The length and width of a engklek has no standard, but usually the length of a square side is $60 \mathrm{~cm}$. The size of the rectangle with a length of $120 \mathrm{~cm}$ and a width of $60 \mathrm{~cm}$ and the size of the equilateral triangle of $60 \mathrm{~cm}$ and the diameter of the circle of gacuk is a $5 \mathrm{~cm}$ long.

Those, it can be used by teachers in implementing the concept of geometry and circumference area such as square, rectangle, triangle, and circle. Alternatives to seek circumference and geometry area by measuring the arena game or playground with yarn and a wooden ruler, and pieces of square shaped cardboard.

\subsection{Dam-Daman Game (Checkers)}

Prastika \& Sukadi (2015) states that checkers is a games of defense and attack types 
such as chess. The game is a line formed in such a manner and stone or tile with two different groups. Two players take turns attacking each other to devour his troops and also survive.

Players who manage to eat all the opposing forces or pawn will be the winner. The pawns are made of gravel and broken roof tiles. The arena and and the pieces of pawns of damdaman (checker) can be seen in Figure 3.
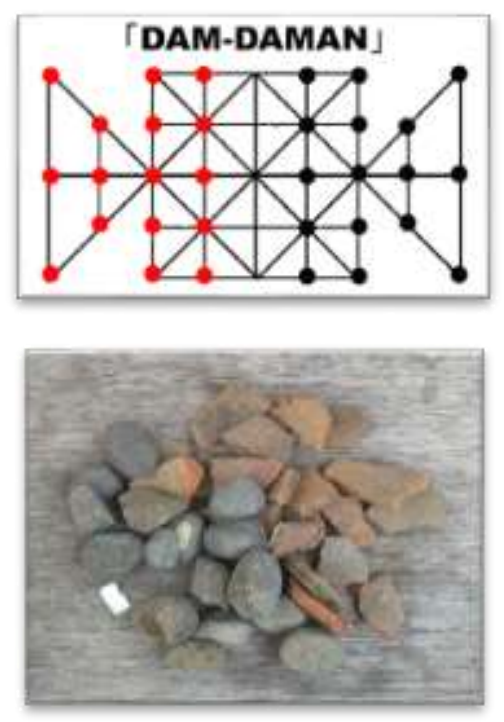

Figure 3. The Arena and Pawns of Dam-Daman

The game is played on a board or cardboard that has been drawn. In this game, there are 16 pieces of pawns for each player. The purpose of the game is to spend a pawn of the opponent with the rules that have been agreed as the end of game. The following Figure 4 is the rules for spending a pawn in the game of dam-daman.

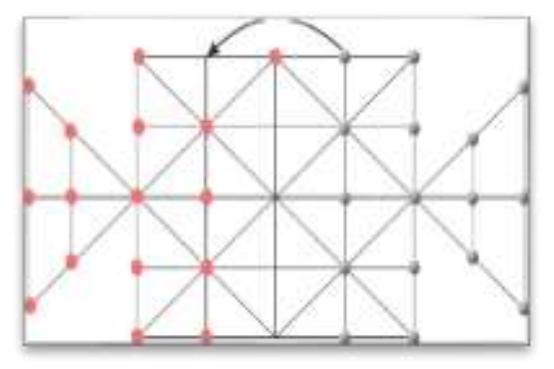

Figure 4. The Rules for Spending Pawns of Opponent

Febriyanto (2015) suggests the steps of dam-daman as follows: 1) The player consist of two players, 2) players shall looking for pebbles and peices of tile to become the pawn, 3) the number of pieces of pawns for each player are 16 pieces, 4) the image of arena of the games is as shown on Figure 3,5) stacking each piece on the playing area as shown in Figure 3,6) pawns can only move one step to the side, or forward or diagonally, 7) spend the pawn of opponent by crossing pawn opponent, like Figure 4,8 ) do whistling or suit to determine the first turn to play, 9) if a player forgot to spend the pawn, then it considered a dam, and the opponent is entitled to take the pieces belonging to the opponent as much as three pieces and resume the game, 10) the game ends when one player had run out of pawn.

Based on Figure 3 and 4 the arena of dam-daman consists of a large square and two isosceles triangles. Large square made up of a small square, amounting to 16 pieces. The size of the square and the side is tailored to the individual wishes. Generally, the size of the square is small, $6 \mathrm{~cm} \times 6 \mathrm{~cm}$, and an isosceles triangle have a base of $18 \mathrm{~cm}$ and $12 \mathrm{~cm}$ high. This means that the arena game of dam-daman have integrated the concept of geometry of square and isosceles triangle.

\subsection{Gobak Sodor Game}

Gobak sodor or blodoran in Banyumas language is a game that has two groups, they are the group of gobak sodor and the group of doorman or gatekeeper. Players must constitute at least 10 people consisting of 5 players and 5 doorman. The name of groups of doorman in gobak sodor can be seen in Table 1 .

Table 1. Door Guard Name Gobak Sodor

\begin{tabular}{cc}
\hline Doorman & Nick name \\
\hline 1 & Masang Siji or Blodor \\
2 & Masang Loro \\
3 & Masang Telu \\
4 & Masang Papat \\
5 & Masang Lima \\
\hline
\end{tabular}

The location of the game is in a vast land like field. The border line of the arena is marked with the line written with finely ground limestone or wood ashes. The length of the arena of the game for every door that is 4 meters long and 3 meters wide. The arena of gobak sodor game can be seen in Figure 5. 


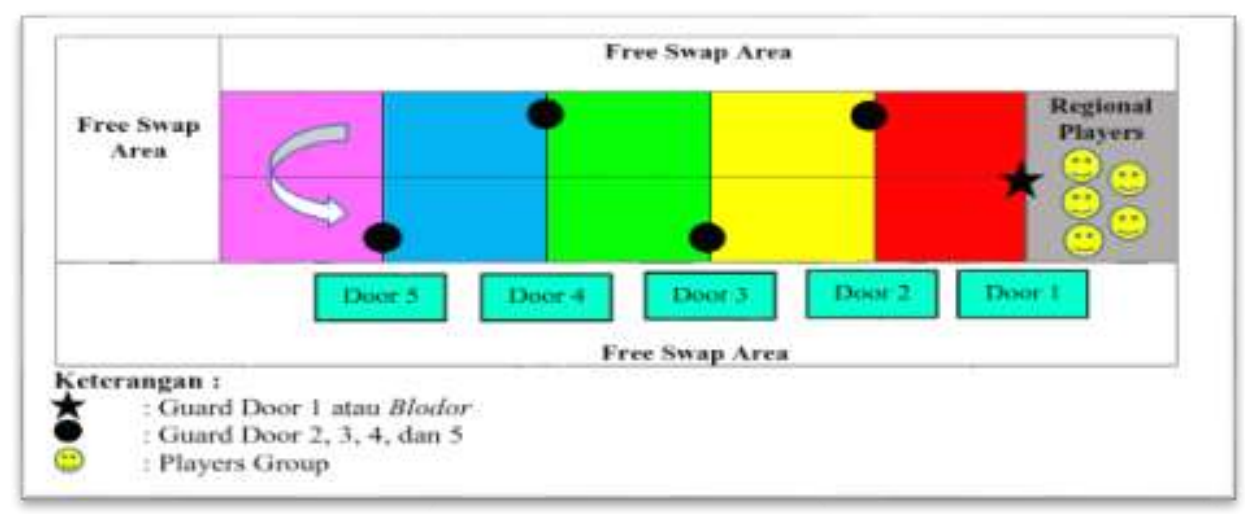

Figure 5. The Arena of Gobak Sodor

The steps of gobak sodor is as follows, 1) the chairman of the group suit for determining of which group to take turn to play at first, second) the group of guards or gatekeeper occupied every door, while the players are in the players area, 3) each player began to enter the door carefully, 4) gatekeeper can turn off or kill the player by touching the body of any player or players enter the free swap area, 5) the player is declared victorious if all players can skip all of the door guarded and return to the players area safely, 6) the player who won the prize shall be picked up by any guards at a distance of five meters.

Based on Figure 5, it can be identified that the arena of gobak sodor game consists of a rectangular geometry. It can be used as an alternative by teachers in presenting the material of circumference and area of a rectangle, students can play gobak sodor and studying the geometry. Students can measure the arena of the game with a ruler or tape measure big rollers.

\subsection{Bandaran Game}

Bandaran game is a kind of game that consists of a group of players and a keeper (bandar). This game uses a rubber band which is rolled up and then thrown to the arena of bandaran. If the rubber being thrown into the arena, then the bandar must provide a rubber band in accordance with the amount that goes into bandaran area. However, if the rubber band falls outside the arena or on the exact bandaran arena, rubber bands players belong to the bandar.

The number of players on the game of bandaran is at least six players consisting of a bandar, and five players. A bandar should have a number of rubber bands that quite a lot. The bandaran game arena can be seen in the following Figure 6.

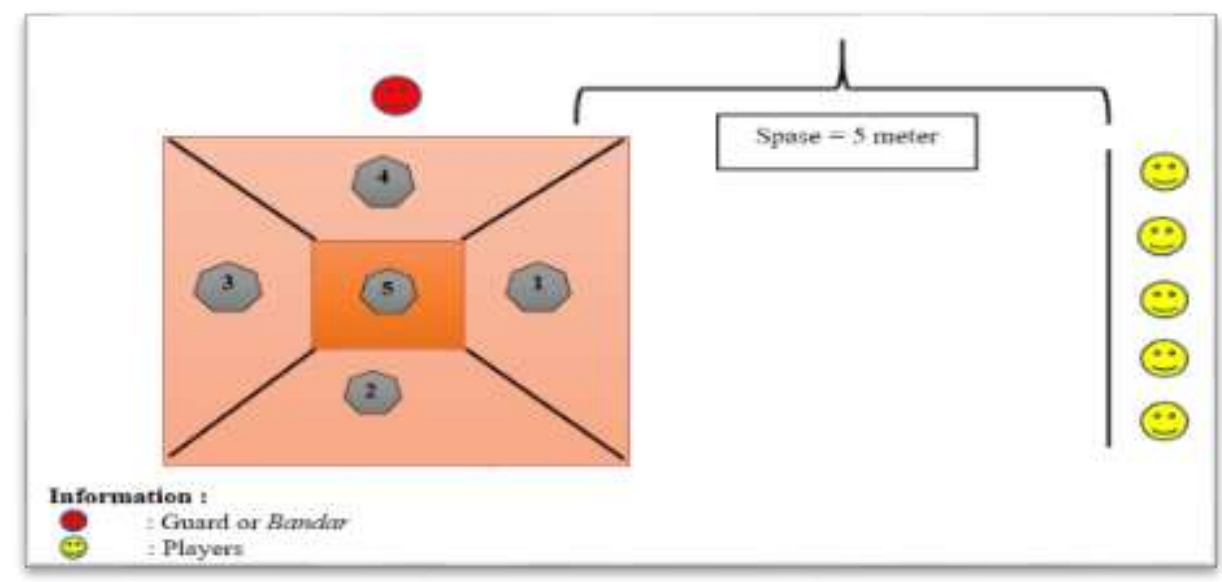

Figure 6. The Arena of Bandaran Game

Based on Figure 6, it can be identified that bandaran game arena consists of a large square of geometry, a small square, and four trapezoidal. It can be used as an alternative by teachers in presenting the material of circumference and area of the square, and 
trapezoidal. Students were invited to play bandaran, while they practicing to count by using a rubber band, and calculate concept of the circumference and area of geometry on a square and a trapezoid.

\section{Conclusion}

Based on the results and the above discussion, Banyumas Regency, Central Java, Indonesia various games such as engklek (hopscotch), dam-daman (checker), gobak Sodor, and bandaran have a relationship with etnomatematics which is the concept of geometry, such as rectangular, trapezoid, triangle, and circle. It can be used by students as a means of learning resources two dimensional figures in primary school.

\section{References}

Fauzi, Pembentukan Karakter Anak Melalui Permainan Tradisional Cim-Ciman, $J$. Ilmiah Visi PPTK PAUDNI. 11(2) (2016) 99-109.

Febriyanto, P., Penerapan Alogaritma Negamax untuk Menghasilkan Langkah yang Optimal pada Permainan Dam-Daman, J. Ilmiah Komputer dan Informatika. 1(1) (2015) 1-10.

Gie, T.L., Filsafat Matematika. (Yogyakarta: Yayasan Studi Ilmu dan Teknologi, 1999).

Hiebert, J. \& Carpenter, T.P., Learning with understading. Dalam D.G. Grouws $(E d)$, Handbook of Research on
Mathematics Reaching and Learning. (New York: Macmillan, 1992).

Hudojo, H., Mengajar Belajar Matemaika. (Jakarta: Departemen Pendidikan dan Kebudayaan Direktorat Jenderal Pendidikan Tinggi Proyek Pengembangan Lembaga Pendidikan Tenaga Kependidikan, 1998).

Kusnandar \& Nurcahyo, P.J., Pemanfaatan Permainan Tradisional Banyumas GolGolan sebagai Materi Pembelajaran Penjas di Sekolah Dasar di Kabupaten Banyumas. (Prosiding Seminar Nasional dan Call For Papers Pengembangan Sumber Daya Pedesaan dan Kearifan Lokal Bekelanjutan VII, pada tanggal 17-18 November 2017 di Purwokerto, 2017).

Prastika, P., \& Sukadi., Pembuatan Game DamDaman Menggunakan Java. J. Indonesia Jurnal on Computer Science. (2015) 2088-2154.

Setiyadi, D., Zaenuri \& Mulyono, The Problem Based Learning Model with Etnomatematics Nuance by Using Traditional Games to Improve Problem Solving Ability. J. Journal of Primary Education, 7(2) (2018) 179 - 186.

Yusuf, M.W., Ethnomathematics (a Mathematical Game in Hausa Culture). J. International Journal of Mathematical Science Education Technomathematics Research Foundation, (2010). 